\title{
PENGELOLAAN PERIKANAN TONDA DENGAN RUMPON MELALUI PENDEKATAN SOFT SYSTEM METHODOLOGY(SSM) DI PPP PONDOKDADAP SENDANG BIRU, MALANG
}

\section{(MANAGEMENT OF TROLL FISHERIES WITH FISH AGGREGATING DEVICE USING SOFT SYSTEM METHODOLOGY (SSM) IN PPP PONDOKDADAP SENDANG BIRU, MALANG)}

\author{
Alvi Rahmah,2, Tri Wiji Nurani², Sugeng Hari Wisudo ${ }^{2,}$ Nimmi Zulbainarni $^{2}$ \\ ${ }^{1}$ Corresponding author \\ ${ }^{2}$ Departemen Pemanfaatan Sumberdaya Perikanan \\ Fakultas Perikanan Dan Ilmu Kelautan, Institut Pertanian Bogor \\ E-mail: alvi.rahma@gmail.com
}

\begin{abstract}
The aims of this study to formulate the problems of troll fisheries in Sendang Biru from the technical, ecological, and institutional aspects, in order to discover the conceptual model as a solution to the problems. Research was conducted in February 2013 in PPP Pondokdadap, using Soft Systems Methodology (SSM). The results showed that problems were the existence of competition for troll fisheries unit area, smaller size tuna were obtained, and weak institutional role in the monitoring and licensing of fishing. Therefore, there are 3 conceptual models into the initial solution that can be done by all parties concerned, namely (1) formulating the fishing operation of troll fisheries with FAD unit in PPP Pondokdadap, (2) developing and implementating of local regulation for monitoring, controlling, and survaillance of fishing ground in Southern water of Malang Regency, and (3) manufacturing and using of SOP licensing by local government.
\end{abstract}

Keywords: Troll fisheries, management of fisheries, soft system methodology

\section{ABSTRAK}

Penelitian ini bertujuan untuk memformulasikan permasalahan perikanan tonda di Sendang Biru dari aspek teknis, ekologi, dan kelembagaan, sehingga dapat ditemukan model konseptual sebagai solusi terhadap permasalahan yang ada. Penelitian dilakukan pada bulan Februari 2013 di PPP Pondokdadap, dengan menggunakan metode Soft System Methodology (SSM). Hasil penelitian menunjukkan bahwa terdapat permasalahan secara teknis, ekologi, dan kelembagaan, yaitu adanya persaingan wilayah penangkapan unit perikanan tonda, semakin kecilnya ukuran ikan tuna yang diperoleh, dan masih lemahnya peran kelembagaan dalam pengawasan dan perizinan perikanan. Oleh karena itu, terdapat 3 model konseptual yang direkomendasikan sebagai solusi awal yang dapat dilakukan oleh seluruh pihak terkait, yaitu (1) pembuatan peraturan operasional penangkapan bagi unit perikanan tonda dengan rumpon di PPP Pondokdadap, (2) pembuatan dan pelaksanaan peraturan lokal pengawasan perairan, dan (3) pembuatan dan penggunaan SOP perizinan oleh pemerintah daerah.

Kata kunci: Perikanan tonda, sistem perikanan, soft system methodology

\section{PENDAHULUAN}

Peningkatan dan perkembangan permintaan pasar serta jumlah produksi yang dihasilkan pelabuhan perikanan di Indonesia terhadap komoditas perikanan saat ini merupakan salah satu alasan pemerintah untuk mencanangkan program industrialisasi perikanan khususnya jenis tuna, tongkol, dan cakalang (TTC). Kabupaten Malang merupakan salah satu wilayah yang berpotensi untuk mendukung program industrialisasi tersebut. Pelabuhan Perikanan Pantai (PPP) Pondokdadap di Dusun Sendang Biru menjadi penyumbang terbesar terhadap jumlah produksi TTC Kabupaten Malang, dengan produksi tahun 2012 mencapai 3787 ton. Tingginya produksi tersebut diduga karena posisinya yang strategis, yaitu berada di dekat Samudera Hindia yang merupakan daerah penangkapan potensial jenis TTC dan adanya Pulau Sempu sebagai breakwater alami yang memberikan keamanan pada kapal yang ingin berlabuh dan mendaratkan hasil tangkapannya (UPPPP Pondokdadap, 2013).

Komoditas TTC banyak ditangkap menggunakan alat tangkap pancing 
dengan kapal tonda atau yang dikenal dengan sekoci. Kapal tonda di PPP Pondokdadap terus meningkat, terlihat dari perkembangan jumlah kapal tonda. Tahun 2007 jumlah kapal tonda sebanyak 318 unit dan pada tahun 2012 meningkat menjadi 366 unit. Pengoperasian kapal tonda ini dibantu de-ngan menggunakan alat bantu penangkapan yang dikenal dengan rumpon, dimana setiap satu rumpon dimanfaatkan oleh 1 kelompok kapal yang terdiri dari 5-9 unit kapal tonda. Peningkatan jumlah kapal yang beroperasi dan pemanfaatan rumpon ternyata berakibat pada konflik horizontal karena perebutan daerah penangkapan dan tidak berizinnya pengoperasian unit perikanan tonda dan rumpon, yang dikhawatirkan akan mempengaruhi kondisi sumberdaya ikan. Hermawan (2011) menyatakan bahwa hasil tangkapan tuna dan cakalang yang didaratkan di PPP Pondokdadap sebagian besar didominasi oleh ikan yang berukuran kecil atau tidak layak tangkap.

Kemampuan PPP Pondokdadap dalam mendukung program industrialisasi dari pemerintah dapat terlaksana dengan baik jika seluruh permasalahan tersebut dapat diminimalisir dan diselesaikan dengan cara yang tepat. Penyelesaiannya akan dilakukan melalui penelitian ini, dimana penelitian ini bertujuan untuk (1) memformulasikan permasalahan yang ada berdasarkan aspek teknis, ekologi, dan kelembagaan; dan (2) membuat model konseptual sebagai solusi terhadap permasalahan pada sistem perikanan tonda dengan rumpon di PPP Pondokdadap. Hasil penelitian ini diharapkan dapat membuat pelaksanaan operasional unit perikanan tonda dengan rumpon di Sendang Biru berjalan optimal dengan tetap memperhatikan keterkaitan antara aspek teknis, ekologi, dan kelembagaan, sehingga memiliki kemampuan untuk berkontribusi dalam program industrialisasi TTC yang digalakkan oleh pemerintah.

\section{METODOLOGI}

\subsection{Waktu dan Tempat Penelitian}

Penelitian dilaksanakan pada bulan Februari 2013 di Pelabuhan Perikanan Pantai (PPP) Pondokdadap, Dusun Sendang Biru, Desa Tambakrejo, Kecamatan
Sumbermanjing Wetan, Kabupaten Malang, Provinsi Jawa Timur.

\subsection{Metode Pengumpulan Data}

Data diperoleh melalui wawancara dan survei berdasarkan kuesioner yang telah dibuat sebelumnya. Kuesioner dibuat dalam bentuk pertanyaan terbuka agar informasi diperoleh secara lebih mendalam. Sampel diambil secara sengaja dengan menggunakan metode purposive sampling (Sugiyono, 2007). Pengambilan sampel berdasarkan pertimbangan karakteristik pada tiap sampel yang akan diambil. Responden yang dijadikan sampel merupakan responden kunci dari unit perikanan tonda, mewakili orang-orang yang terlibat dalam perikanan tonda, yaitu pemilik dan nakhoda kapal sebanyak 11 orang, pengambek 2 orang, Kepala UPPPP Pondokdadap 1 orang, dan Kepala seksi perikanan tangkap DKP Kabupaten Malang 1 orang. Penentuan jumlah responden tidak diperlukan dalam penelitian ini, karena peneliti akan berhenti dalam proses pengambilan data saat data yang diperoleh dari responden dianggap mencukupi tujuan penelitian.

Data yang dikumpulkan adalah data primer dan sekunder. Data primer berupa informasi mengenai unit perikanan tonda secara detail, berupa teknis pengoperasian (waktu penangkapan, spesifikasi kapal, alat tangkap, dan alat bantu penangkapan, serta daerah penangkapan) unit perikanan tonda, jumlah dan ukuran rata-rata hasil tangkapan, hubungan sosial nelayan, potensi konflik nelayan, pengaruh keberadaan unit perikanan tonda terhadap kondisi masyarakat dan kelembagaan nelayan unit perikanan tonda di Sendang Biru. Data sekunder berupa kondisi geografis dan topografis Sendang Biru, kelembagaan di PPP Pondokdadap Sendang Biru, data jumlah unit perikanan tonda selama 5 tahun terakhir, dan data pendukung lainnya.

\subsection{Analisis Data}

Data yang diperoleh berdasarkan hasil survei dan wawancara dengan responden, kunci dikumpulkan dan ditabulasi serta diambil rataan atau jawaban yang paling dominan dari seluruh responden. Jawaban tersebut yang dijadikan sebagai informasi akhir atau data akhir, yang selanjutnya akan 
dianalisis dengan menggunakan pendekatan Soft System Methodology (SSM). Fokus penelitian terhadap masalah yang dibagi dalam 3 aspek kajian (teknis, ekologi, dan kelembagaan) dikarenakan masalah yang terjadi pada aspek tersebut merupakan permasalahan yang paling disoroti nelayan dan pemerintah setempat berdasarkan hasil survei dan wawancara yang dilakukan. Pendekatan SSM terdiri dari 7 tahap (Checkland dan Jim, 1990), namun pada penelitian ini analisis hanya dilakukan sampai tahap yang ke4. Tahapan analisis yang sama dilakukan pada setiap aspek kajian. Adapun tahapannya terdiri atas:

(1) Tahap 1 dan 2 menemukan masalah, menggunakan rich picture dalam mencari situasi masalah. Rich picture berguna untuk melihat pola hubungan tiap masalah pada aspek kajian berdasarkan aktor yang terlibat. Halhal yang harus dimasukkan dalam rich picture adalah pihak yang terlibat, konflik, struktur dan proses yang terjadi, serta persoalan diantara para pihak (Williams, 2005). Penemuan masalah pada penelitian ini dilihat berdasarkan 3 aspek penting, yaitu (a) aspek teknis yang meliputi teknis pengoperasian unit perikanan tonda; (b) aspek ekologi yang menginterpretasikan pengaruh pengoperasian unit perikanan tonda terhadap kondisi sumberdaya ikan yang menjadi target tangkapan; dan (c) aspek kelembagaan yaitu kondisi sosial masyarakat nelayan di Sendang Biru beserta seluruh peraturan (formal dan non-formal) yang terkait dengan nelayan dan pengoperasian unit perikanan tonda. Penemuan masalah dilakukan dengan mengidentifikasi ke-terkaitan setiap masalah yang disebabkan oleh masing-masing aktor yang terlibat dan digambarkan dalam rich picture;

(2) Tahap 3 memformulasi root definetion dari sistem relevan. Rich picture dianalisis lebih lanjut dengan mengidentifikasi elemen-elemen pada setiap masalah dengan root definition. Checkland (2000) dalam Widjajani et al (2009) menyatakan bahwa root definitions dibangun sebagai suatu ekspresi dari aktivitas bertujuan terhadap suatu proses transformasi (T). Root definition dinyatakan dengan spesifikasi yang lebih luas sehingga $T$ dapat dielaborasi dengan mendefinisikan elemen-elemen lain yang membentuk CATWOE (customers, actors, transformation process, weltanschauung, owners, and environmental constraints). Customers merupakan pihak yang menerima dampak proses transformasi; actors adalah orang yang melakukan aktivitas-aktivitas pada proses transformasi; transformation process merupakan proses yang mengubah input menjadi output; weltanschauung adalah sudut pandang, kerangka kerja, atau image yang membuat proses transformasi bermakna; owners adalah orang yang memiliki kepentingan terbesar terhadap sistem dan dapat menghentikan proses transformasi, dan environmental constraints adalah elemenelemen diluar sistem yang dapat mempengaruhi tetapi tidak dapat mengendalikan sistem tersebut atau dapat dinyatakan sebagai apa adanya (given). Elemen-elemen tersebut selanjutnya dinyatakan dalam bentuk $\mathrm{PQR}$, yaitu melakukan $\mathrm{P}$ dengan menggunakan $Q$ untuk dapat berkontribusi dalam mencapai $R$.

(3) Tahap 4 membangun model konseptual berdasarkan root definitions yang telah dibuat sebelumnya. Pembuatan model konseptual yang baru dapat dilakukan jika suatu aspek kajian belum mempunyai pola sistem yang sudah berjalan. Jika aspek kajian sudah memiliki pola sistem yang berjalan, maka yang perlu dilakukan adalah memperbaiki atau menambahkan tahapan agar sistem dapat diperbaiki dan berjalan normal sesuai tujuan yang diinginkan;

(4) Tahap 5 membandingkan model dengan dunia nyata;

(5) Tahap 6 menetapkan perubahan yang layak, membuat debat publik untuk mengindentifikasi perubahan yang layak; dan

(6) Tahap 7 melakukan tindakan perbaikan.

Analisis yang dilakukan pada aspek teknis dimulai dengan merincikan teknis pengoperasian unit perikanan tonda secara deskriptif dan masalah yang terjadi pada aspek teknis berdasarkan wawancara serta menghitung nilai produktivitas alat tangkap dan nelayan selama 5 tahun terakhir. Perhitungan nilai produktivitas diperoleh dengan 
menggunakan rumus berikut (Gulland 1991 dalam Astuti, 2005):

$$
\text { CPUE }=\frac{C_{t}}{E_{t}}
$$

dimana: CPUE $=$ Catch per unit effort

$$
\begin{aligned}
\mathrm{C}_{\mathrm{t}}= & \text { hasil tangkapan pada } \\
& \text { tahun ke-t (ton) } \\
\mathrm{E}_{\mathrm{t}}= & \text { upaya penangkapan pa- } \\
& \text { da tahun ke-t (unit/ } \\
& \text { nelayan) }
\end{aligned}
$$

Pada aspek ekologi, analisis dilakukan dengan terlebih dahulu mendeskripsikan kondisi hasil tangkapan secara detail, baik dalam hal ukuran, rata-rata jumlah tangkapan per unit kapal, dan masalah yang terjadi terkait hasil tangkapan yang diperoleh nelayan unit perikanan tonda selama 5 tahun terakhir. Perincian juga dilakukan pada aspek kelembagaan dengan mengidentifikasi kondisi nelayan secara sosial dan peran kelembagaan terhadap keberlangsungan unit perikanan tonda di Sendang Biru. Keseluruhan proses analisis merupakan tahapan dengan pendekatan SSM.

Penelitian ini memiliki latar belakang masalah yang cukup kompleks sehingga diperlukan penyelesaian dengan pendekatan sistem, seperti pendekatan SSM. Tujuannya agar akar masalah pada setiap aspek kajian dapat diselesaikan secara baik. Kelebihan pendekatan SSM dibandingkan pendekatan sistem lainnya adalah pengidentifikasian masalah lebih mendalam dan terstuktur serta keterkaitan antar pihak dan masalah yang terlibat dalam sistem lebih terlihat dengan adanya penggambaran masalah dari rich picture. Pendekatan SSM juga menghasilkan model konseptual yang dapat dijadikan salah satu acuan dalam memperbaiki sistem yang ada. Model konseptual yang dihasilkan lebih aplikatif karena pembentukannya didasarkan pada elemen-elemen (CATWOE) yang diidentifikasi berdasarkan masalah pada setiap aspek kajian.

\section{HASIL DAN PEMBAHASAN}

\subsection{Formulasi Masalah pada Unit Perikanan Tonda dengan Rumpon di PPP Pondokdadap \\ (1) Aspek Teknis}

Informasi yang diperoleh dari responden menunjukkan bahwa penggunaan alat tangkap pada unit perikanan tonda oleh nelayan secara teknis me- miliki spesifikasi alat tangkap, rumpon, dan kapal yang sama. Jenis alat tangkap yang digunakan adalah pancing, dengan menggunakan kapal berukuran rata-rata 10 GT. Perbedaannya hanya terletak pada penggunaan metode penangkapan. Nelayan menamai jenis pancing sesuai dengan metode penangkapan yang digunakan. Jenis pancing yang digunakan oleh nelayan terdiri atas pancing tonda, taber, layangan, tomba, batuan, coping, dan ulur. Perbedaan dari 7 jenis pancing tersebut adalah cara operasi, umpan, dan jenis serta ukuran mata pancing yang digunakan.

Nelayan berangkat dari fishing base (pelabuhan) pada pagi atau sore hari menuju fishing ground yang pertama. Fishing ground yang pertama adalah tempat dimana nelayan meletakkan rumpon dengan jarak terdekat, yaitu sekitar 50 mil dari garis pantai. Perjalanan dari fishing base ke fishing ground yang berjarak 50 mil sekitar 5 jam, sedangkan ke rumpon yang berjarak 100 mil keatas menghabiskan waktu sekitar 1-3 hari. Nelayan menggunakan kompas dan GPS untuk membantu mencari lokasi rumpon kelompoknya. Nelayan baru melakukan operasi penangkapan dengan metode penangkapan yang sesuai dengan kondisi perairan saat itu setelah menemukan rumpon milik kelompoknya. Sebagian besar nelayan tonda menggunakan pancing "taber" sebelum subuh, dan akan melanjutkan menggunakan pancing tonda saat matahari terbit atau sekitar pukul 06.30 WIB. Tidak ada aturan pasti mengenai urutan penggunaan metode penangkapan yang dilakukan oleh nelayan pada setiap unit kapal tonda. Jenis metode penangkapan ini diperoleh berdasarkan uji coba yang dilakukan oleh nelayan ketika mengoperasikan alat tangkap.

Pengoperasian alat tangkap pancing dengan metode penangkapan yang beragam pada unit perikanan tonda dengan rumpon di PPP Pondokdadap merupakan salah satu indikasi bahwa nelayan tonda memiliki kemampuan yang cukup baik dalam mengoperasikan alat tangkap secara teknis. Kemampuan tersebut biasanya didasarkan pada pengalaman melaut nelayan. Perolehan hasil tangkapan yang tidak pasti pada setiap kali operasi penangkapan membuat nelayan dituntut untuk memiliki kreativitas dalam mengembangkan metode atau 
cara penangkapan untuk memperoleh target tangkapan yang optimal. Terlebih lagi dengan terbatasnya wilayah penangkapan yang menjadi permasalahan teknis pada perikanan tonda di PPP Pondokdadap. Keterbatasan tersebut dikarenakan semakin banyaknya rumpon yang dipasang di perairan. Pemanfaatan rumpon di Sendang Biru tidak hanya dilakukan oleh nelayan unit perikanan tonda saja, melainkan juga oleh unit perikanan lainnya seperti purse seine. Sondita (2011) menyatakan bahwa pemanfaatan rumpon seharusnya tidak hanya terbatas pada alat bantu penangkapan yang mengumpulkan ikan saja, sehingga nelayan dapat menghemat biaya operasional dan daerah penangkapan menjadi lebih pasti. Rumpon dapat dimanfaatkan sebagai salah satu alat untuk mengelola sumberdaya perikanan, khususnya sumberdaya ikan pelagis. Rumpon bisa dijadikan alat untuk menilai jumlah ikan yang dapat ditangkap, kelayakan ikan yang ditangkap (jenis dan ukuran ikan), dan menentukan pembagian ikan diantara nelayan. Fungsi tersebut akan dapat berjalan jika seluruh pihak telah benarbenar mengerti tentang pemanfaatan rumpon secara tepat.

Beberapa hal yang harus diperhatikan dalam pemasangan dan penempatan rumpon di perairan yaitu penggunaan bahan pembuat rumpon berasal dari bahan organik dan dapat terdegradasi secara alami, pola pemasangan tidak boleh menghalangi pola alami ruaya ikan, hindari penempatan rumpon pada daerah yang sering dipergunakan oleh nelayan lain, dan jarak antar rumpon harus lebih dari 10 mil laut. Kemungkinan yang akan terjadi jika pemanfaatan rumpon menjadi tidak terkendali adalah semakin banyak jumlah rumpon yang dipasang, terjadinya overfishing, dan berpengaruh terhadap fungsi ekologi yaitu sumberdaya ikan yang terdapat di perairan (Habibi et al, 2011). Pendugaan telah terjadinya tekanan penangkapan atau overfishing pada daerah penangkapan unit perikanan tonda nelayan Sendang Biru terlihat dari perhitungan nilai rata-rata produktivitas alat tangkap dan nelayan yang menurun pada tahun 2012 dibanding pada tahun 2010, yaitu sebesar 0.13 ton/unit (Gambar 1a) dan 0.03 ton/orang (Gambar 1b), dimana saat effort ditambahkan yang terjadi adalah penurunan rata-rata produksi yang dihasilkan oleh unit perikanan tonda.

Indikasi tekanan penangkapan ini juga diteliti oleh Saputra (2011) yang menunjukkan bahwa kecilnya hasil tangkapan per trip (CPUE) ikan pelagis besar yang tertangkap, yaitu sebesar 2.25 ton/trip/tahun dengan rata-rata produktivitas kapal tuna longliner sebesar 0.045 ton/GT/tahun. FAO (2007) dalam Saputra (2011) juga menyebutkan bahwa kondisi sumberdaya ikan di sekitar perairan Samudera Hindia dan Samudera pasifik sudah full exploited.

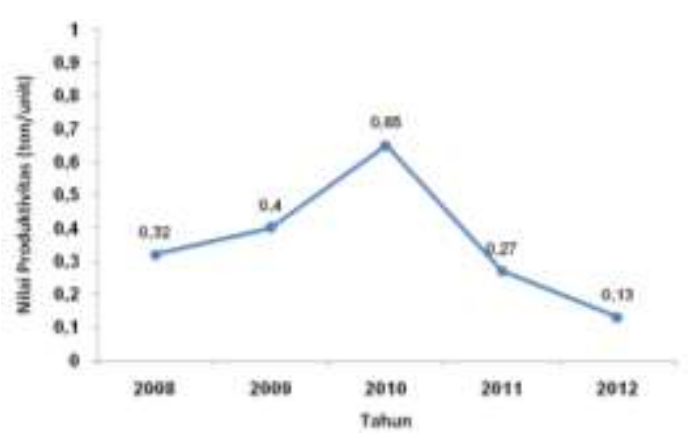

(a)

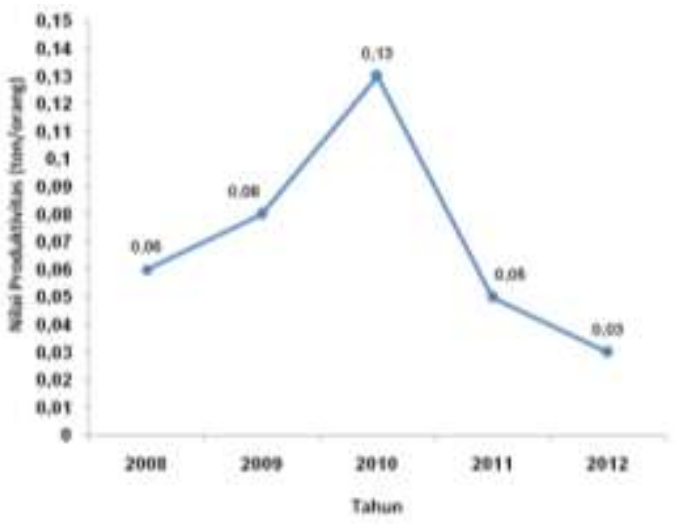

(b)

Gambar 1. Rata-rata produktivitas alat tangkap (a) dan nelayan (b) unit perikanan tonda dengan rumpon di PPP Pondokdadap tahun 2008-2012 
Perairan Prigi yang termasuk dalam perairan Selatan Jawa juga mengalami tekanan penangkapan untuk jenis tuna, seperti hasil penelitian Ross (2011) yang menyatakan bahwa jenis tuna mengalami kelebihan tangkap sebesar 39\% dari potensi lestari atau sama dengan 614.35 ton/tahun selama lima tahun terakhir.

\section{(2) Aspek Ekologi}

Hasil tangkapan tuna yang didaratkan di PPP Pondokdadap pada bulan Juni dan Desember 2012 mempunyai berat berkisar antara $15 \mathrm{~kg}$ hingga $76 \mathrm{~kg}$ per ekornya. Berat ikan cakalang sekitar $1.5-2.2 \mathrm{~kg}$, marlin 34 $\mathrm{kg}$, tongkol $1.8 \mathrm{~kg}$, dan lemadang $24 \mathrm{~kg}$. Rata-rata hasil tangkapan pada bulan Juni 2012 didominasi oleh ikan tuna madidihang sebanyak $543.94 \mathrm{~kg}$ atau sebesar $43 \%$ jika dibandingkan dengan total tangkapan (Gambar 2a). Komposisi hasil tangkapan tonda per trip pada musim sedang seperti pada bulan Desember rata-rata terdiri atas ikan tuna, cakalang, tongkol, dan lemadang. Ikan cakalang merupakan jenis yang paling banyak tertangkap pada bulan Desember, yaitu sebanyak $527.83 \mathrm{~kg}$ atau $34 \%$ dari total tangkapan (Gambar $2 b)$.

Berdasarkan wawancara dengan responden diketahui bahwa ukuran hasil tangkapan yang diperoleh pada setiap trip cenderung menurun, khususnya jenis ikan tuna. Kecenderungan menurunnya ukuran hasil tangkapan ini merupakan salah satu indikasi terjadinya tekanan penangkapan di wilayah pengoperasian unit perikanan tonda, yaitu di sekitar Samudera Hindia. Zulbainarni (2012) menyatakan bahwa sumberdaya perikanan yang bersifat common property (kepemilikan bersama) memungkinkan terjadinya pemanfaatan secara berlebih sehingga menimbulkan inefisiensi dalam penggunaan input, return yang rendah, dan overfishing (tangkap lebih). Clark (1985) dalam Zulbainarni (2012) juga menyebutkan bahwa overfishing secara biologi dapat terjadi kapan saja bila perbandingan antara harga dan biaya yang cukup tinggi.

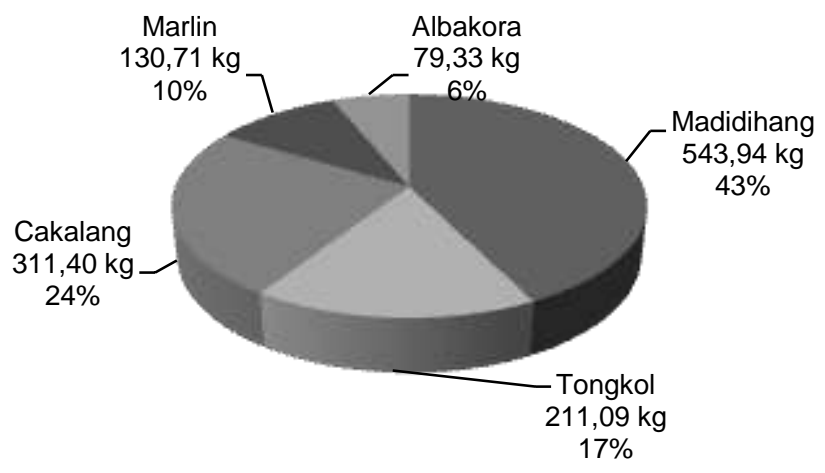

(2a)

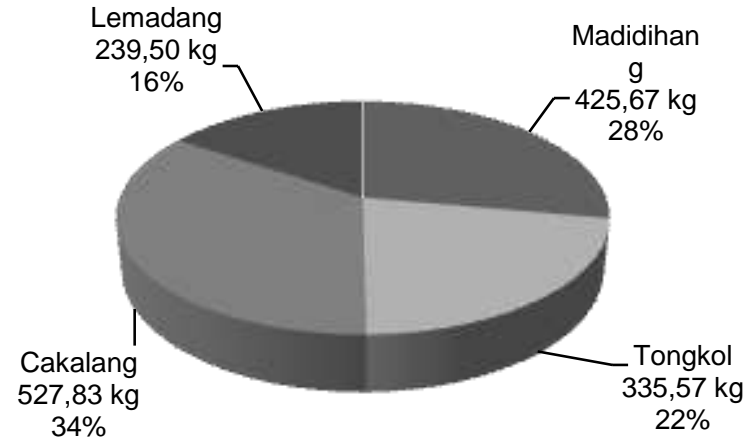

(2b)

Gambar 2. Komposisi dan persentase hasil tangkapan tonda per jenis ikan (kg) per trip pada bulan Juni (a) Desember (b) tahun 2012 
Pillai dan Satheeshkumar (2012) menyatakan bahwa operasi penangkapan dapat berdampak terhadap kondisi ekologi seperti terhadap hasil tangkapan, habitat, kematian sumberdaya karena alat tangkap yang hilang, polusi, dan lain sebagainya. Kondisi yang sudah dirasakan nelayan tonda di Sendang Biru saat ini adalah ukuran hasil tangkapan khususnya ikan tuna yang mulai mengecil. Pillai dan Satheesshkumar (2012) juga menyebutkan bahwa produksi ikan tuna di Samudera Hindia menurun menjadi 913625 ton pada tahun 2008. Analisis data secara jelas menunjukkan bahwa populasi ikan tuna di Samudera Hindia mengalami overexploited. Produksi ikan cakalang pada tahun 2010 berjumlah 429.729 ton, yang menjadi produksi terendah sejak tahun 1998; produksi ikan madidihang pada tahun 2009 sebesar 268.192 ton dengan berat rata-rata $10-20 \mathrm{~kg}$ (tahun 1996) dan menurun menjadi 6-15 kg untuk tahuntahun selanjutnya.

\section{(3) Aspek Kelembagaan}

Peran kelembagaan khususnya organisasi nelayan dalam mengatur perikanan sebenarnya cukup besar, salah satunya dengan menjaga keamanan laut dari penjarahan unit penangkapan milik nelayan luar terhadap wilayah operasi penangkapan nelayan setempat dan sumberdaya ikan yang terdapat di dalamnya. Penjagaan tersebut dapat dilakukan dengan membantu pengawasan wilayah perairan. Peran tersebut harus didukung dengan partisipasi aktif dari seluruh masyarakat nelayan, namun hal yang sering terjadi adalah suatu organisasi nelayan belum cukup mampu untuk membantu mengatur perikanan di suatu wilayah. Hal tersebut dikarenakan posisi organisasi nelayan dalam masyarakat belum cukup kuat dan masih kurangnya kesadaran nelayan secara individu maupun kelompok dalam menjaga perairan.

Nelayan sebagai pelaku utama sudah seharusnya memahami peraturan yang berlaku dan harus dipenuhi dalam pengoperasian unit perikanan di daerah penangkapan untuk memanfaatkan sumberdaya ikan. Kurangnya kekompakan diantara nelayan menjadi salah satu penyebab terjadinya masalah sosial dalam masyarakat nelayan, yang akan berpengaruh terhadap sistem perikanan seperti perikanan tonda di Sendang Biru. Kasus yang pernah terjadi dalam kurun waktu 5 tahun terakhir adalah pencurian hasil tangkapan oleh nelayan purse seine Pekalongan dengan memanfaatkan rumpon nelayan tonda Sendang Biru. Hal serupa juga pernah terjadi dengan nelayan asal Tuban. Kasus ini hanya diselesaikan secara kekeluargaan tanpa ada perjanjian tertulis dari kedua belah pihak, sehingga konflik yang sama berpeluang terjadi lagi dikarenakan tidak ada sanksi yang jelas yang diberikan kepada pelaku. Kesepakatan mengenai pemanfaatan rumpon diantara para nelayan tonda Sendang Biru sebenarnya telah dibuat pada tahun 2010, yaitu tidak memanfaatkan rumpon kelompok nelayan lain tanpa izin dari kelompok tersebut dan tidak diperbolehkan menerima hasil tangkapan dari nelayan jaring (seperti purse seine dan payang), jika melanggar akan dikenakan denda, namun pada pelaksanaannya kesepakatan ini tidak berjalan. Kondisi ini memerlukan peran kelembagaan yang lebih kuat, khususnya bagi organisasi nelayan Rukun Jaya dan seluruh nelayan untuk dapat lebih aktif dalam menjalankan kesepakatan sebagai wujud partisipasi dalam menjaga dan mengawasi perairan dan sumberdaya ikan didalamnya.

Sebagian besar unit perikanan tonda dengan rumpon milik nelayan Sendang Biru tidak memiliki dokumen kapal yang lengkap untuk memanfaatkan sumberdaya pada wilayah perairan, padahal pengoperasiannya dilakukan pada wilayah perairan yang cukup jauh yaitu 50-200 mil atau berkisar pada $8^{0}$ $13^{0}$ LS. Rumpon yang dipasang nelayan di perairan juga tidak memiliki izin dari pemerintah, sehingga adanya penambahan atau pengurangan jumlah rumpon setiap periode waktu tertentu tidak tercatat. Pengurusan izin kapal nelayan di PPP Pondokdadap sebenarnya telah dibantu oleh organisasi nelayan Rukun Jaya. Hambatan seperti proses administrasi yang cukup lama dan biaya yang mahal membuat nelayan merasa kewalahan untuk mengurus dokumendokumen tersebut. Kondisi ini menjadi keprihatinan tersendiri, disaat nelayan mulai berusaha untuk memperhatikan dan mengurusi perizinan, petugas perikanan dari pemerintah melakukan tindakan yang tidak sesuai dengan aturan yang ditetapkan. Prosedur pen- 
daftaran dan perizinan kapal sebenarnya telah diatur dalam PER.30/MEN/2012 mengenai usaha perikanan tangkap di wilayah pengelolaan Republik Indonesia, dimana tahapan perizinan dimulai dari pengajuan penerbitan Surat Izin Usaha Perikanan (SIUP); permohonan pemeriksaan fisik kapal, alat penangkapan ikan, dan dokumen kapal penangkap ikan dan/atau kapal pengangkut ikan; dan pengajuan penerbitan Surat Izin Penangkapan Ikan (SIPI) dan Surat Izin Kapal Pengangkut Ikan (SIKPI). Dokumen lainnya yang harus ada di atas kapal yaitu Surat Laik Operasional (SLO) dan Surat Izin Berlayar (SIB) (DJPT, 2013). Kerjasama diantara pihak yang terkait (nelayan, organisasi nelayan, dan pemerintah) sudah seharusnya berjalan. Pengawasan oleh pemerintah pusat (KKP) dan pemerintah daerah (DKP) sangat diperlukan, mengingat secara hukum, pemerintah merupakan pihak yang bertanggungjawab untuk mengelola perikanan.

Kekompleksitasan masalah yang terjadi pada sistem perikanan tonda dengan rumpon di Sendang Biru, seperti yang telah dijelaskan sebelumnya, dapat diselesaikan dengan cara melihat permasalahan tersebut secara sistem dengan menggunakan rich picture (Gambar 3).
Gambar 3 menyajikan permasalahan yang saling terkait yaitu persaingan wilayah penangkapan, pemanfaatan rumpon, dan upaya penangkapan yang meningkat menjadi salah penyebab penurunan produksi dan perubahan ukuran ikan. Terjadinya konflik nelayan, proses perizinan yang lama dan mahal, serta kurangnya pengawasan perairan oleh pemerintah dan masyarakat nelayan membuat permasalahan yang terjadi semakin kompleks. Permasalahan-permasalahan tersebut melibatkan nelayan tonda Sendang Biru, nelayan luar, Rukun Jaya, dan pemerintah sebagai pihak yang berhubungan langsung dengan pengoperasian unit perikanan tonda dengan rumpon di Sendang Biru.

\subsection{Model Konseptual Pengelolaan Perikanan Tonda}

Model konseptual merupakan tindakan penyelesaian terhadap permasalahan yang telah diformulasikan sebelumnya yang digambarkan dengan rich picture. Model konseptual adalah pemikiran secara teoritis terhadap situasi yang terjadi di dunia nyata yang berperan sebagai solusi awal untuk suatu permasalahan.

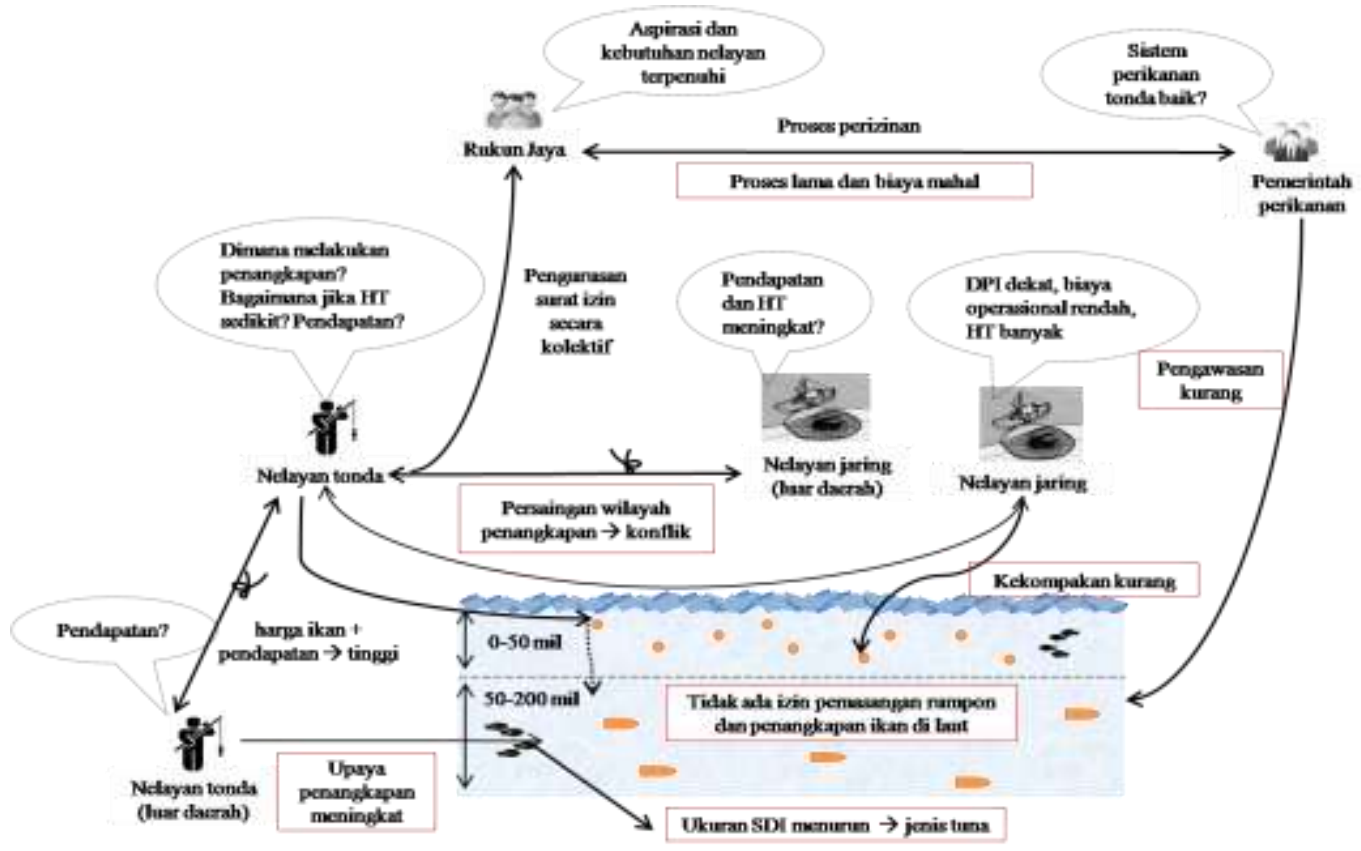

Keterangan: $\square$ permasalahan

Gambar 3. Rich picture terhadap permasalahan teknis, ekologi, dan kelembagaan pada sistem perikanan tonda dengan rumpon di PPP Pondokdadap 
Perumusan model konseptual ini diharapkan dapat memberikan langkah perubahan berupa strategi yang dijalankan untuk memperbaiki sistem. Pembuatan model konseptual didahului dengan memformulasikan root definition berdasarkan elemen-elemen pembentuknya (CATWOE) seperti yang telah dikemukakan pada subbab analisis data sebelumnya. Root definition dijadikan sebagai acuan dalam perumusan model konseptual yang akan direkomendasikan. Penentuan root definition pada aspek teknis dan ekologi (Gambar 4) didasari dari permasalahan yang ada yang selanjutnya digunakan untuk membuat model konseptual menjadi solusi awal terhadap permasalahan yang ada (Gambar 5).

Pembuatan peraturan operasional penangkapan bagi unit perikanan tonda dengan rumpon diharapkan dapat menjadi solusi awal terhadap permasalahan teknis dan ekologi pada sistem perikanan tonda dengan rumpon di PPP Pondokdadap. Langkah untuk meminimalisir masalah teknis dan ekologi berupa persaingan wilayah penangkapan dan penurun ukuran ikan yang diperoleh nelayan adalah dengan mengatur jumlah dan ukuran tangkapan yang diperbolehkan, yang didukung dengan penanganan hasil tangkapan yang sesuai prosedur. Hal ini untuk meningkatkan kualitas ikan yang akan dijual, yang juga akan mempengaruhi harga jual ikan tersebut.
Kualitas hasil tangkapan diperoleh jika kesegaran hasil tangkapan tetap terjaga hingga didaratkan dan dijual di tempat pelelangan. Penanganan hasil tangkapan dapat dilakukan dengan cara mengawetkan hasil tangkapan dengan menggunakan es seperti yang dilakukan nelayan di Indonesia pada umumnya.

Ismanto et al (2013) dalam penelitiannya menyebutkan bahwa sistem pendingin dengan coolbox yang berisi es kering dengan silika gel mampu mempertahankan suhu rendah dalam waktu yang lebih lama namun tidak stabil dibandingkan dengan coolbox yang berisi es basah seperti es batu atau es curah. Lama waktu yang mampu dipertahankan es kering dan silika gel selama 138 jam 30 menit, sedangkan es basah hanya 35 jam. Penanganan lainnya yang dapat dilakukan adalah dengan mengawetkan ikan menggunakan freezer seperti yang dilakukan nelayan purse seine di PPP Bojomulyo. Pengawetan ikan dengan freezer lebih baik jika dibandingkan dengan pengawetan menggunakan es (Hastrini et al, 2013). Tindakan penanganan hasil tangkapan yang paling mendasar yang harus diperhatikan oleh nelayan adalah mencegah kontaminasi langsung antara tangan dan kaki dengan ikan, meminimalisir cahaya matahari langsung yang mengenai tubuh ikan, dan meletakkan serta menyimpan ikan pada wadah yang telah dibersihkan.

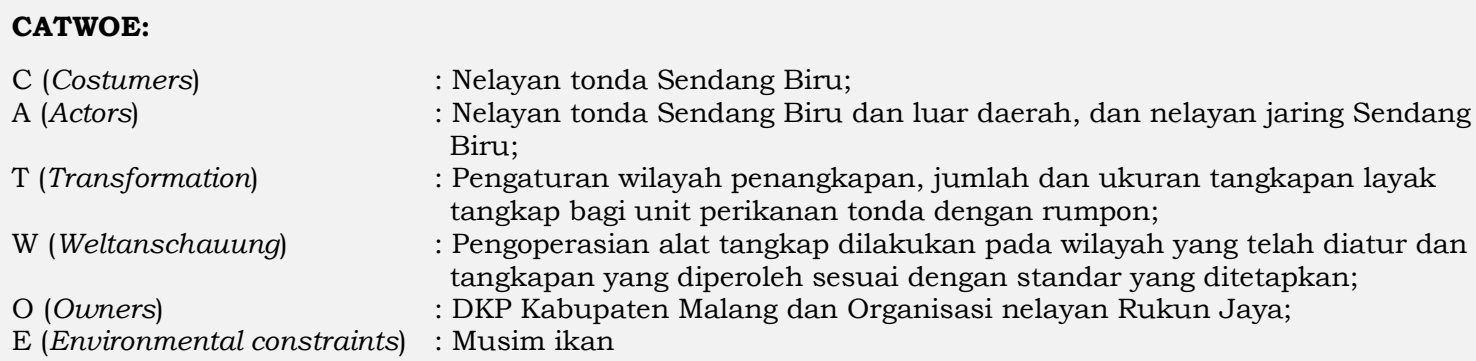

\section{Root definition:}

Pengaturan jumlah dan ukuran tangkapan layak tangkap bagi unit perikanan tonda dengan rumpon melalui pembuatan dan pelaksanaan peraturan operasional penangkapan yang ditetapkan bersama untuk menjaga keberlanjutan sumberdaya ikan.

Gambar 4. CATWOE dan root definition terhadap permasalahan teknis dan ekologi pada unit perikanan tonda dengan rumpon di PPP Pondokdadap 


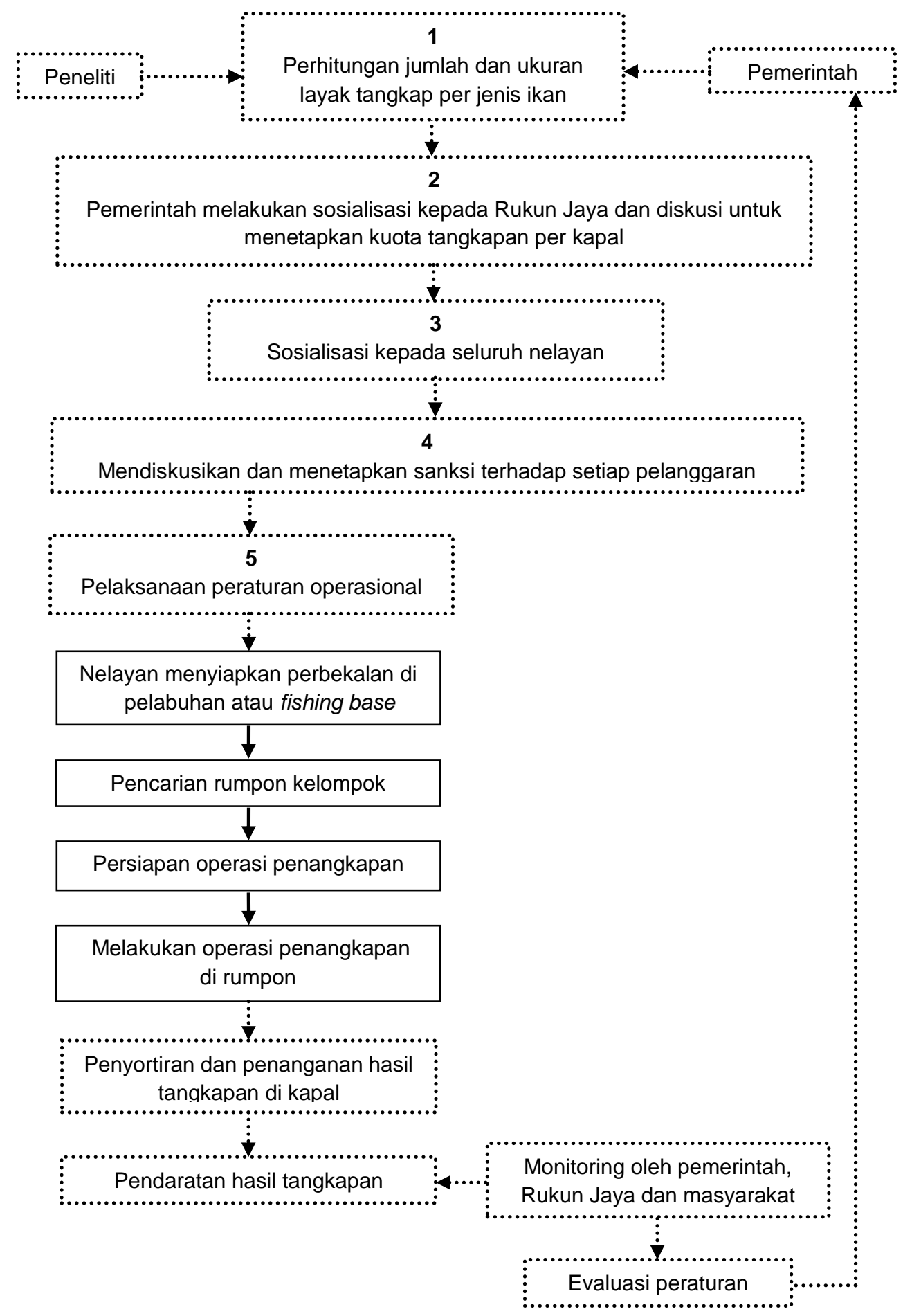

Keterangan: …....: sistem yang diperbaiki/ditambahkan

Gambar 5. Model konseptual pembuatan peraturan operasional penangkapan pada unit perikanan tonda dengan rumpon di PPP Pondokdadap

Root definition dalam aspek kelembagaan terdiri dari 2 bentuk, yang pertama lebih menekankan pada permasalahan kekompakan nelayan, pengawasan, dan konflik yang terjadi (Gambar 6). Peraturan pemerintah berupa keputusan menteri kelautan dan perikanan KEP.58/ MEN/2001 tentang tata cara pelaksanaan sistem pengawasan masyarakat dalam pengelolaan dan pemanfaatan sumberdaya kelautan dan perikanan (DJPSDKP, 2013) menjadi acuan untuk pembuatan 
root definition ini. Pengawasan tersebut dapat diwujudkan jika hubungan sosial masyarakat nelayan dalam kondisi yang baik. Masyarakat nelayan adalah pihak yang membangun lembaga nelayan, sehingga dengan semakin kuatnya hubungan diantara masyarakat nelayan maka akan menguatkan peran kelembagaan.

Penyelesaian terhadap permasalahan pengawasan perairan dapat dilakukan dengan membuat dan melaksanakan peraturan lokal yang merupakan hasil kesepakatan diantara seluruh elemen masyarakat (Gambar 8). Hasil penelitian Martin dan Irmayanti (2011) menunjukkan bahwa masyarakat nelayan Sendang Biru memiliki tradisi yang dikenal dengan nama "ritual petik laut" setiap tanggal 27 September. Ritual ini berfungsi untuk membina solidaritas antar masyarakat nelayan dalam bekerja dan kearifan lokal dalam menjaga lingkungan perairan dan sumberdaya perikanan. Namun kenyataannya, kegiatan ini tidak terlalu memberi pengaruh terhadap kondisi ekologi, sosial, dan kelembagaan di masyarakat.

Diperlukan tindakan pendukung yang bersifat lokal lainnya, seperti pola kearifan lokal masyarakat Aceh yang dikenal dengan hukom adat laot dan dipimpin oleh panglima laot. Panglima laot berwenang untuk mengawasi operasi penangkapan ikan di laut, menyelesaikan perselisihan, menyelenggarakan upacara adat laot, dan menjadi penghubung antara nelayan dengan pemerintah dan antara panglima laot satu dengan lainnya.
Keberadaan panglima laot didukung dengan adanya peraturan dan sanksi yang dipatuhi oleh nelayan dan sangat didukung oleh pemerintah daerah (Sulaiman, 2010). Cara lainnya dengan membentuk pokmaswas (kelompok masyarakat pengawas) seperti yang terdapat di Kabupaten Sukabumi Jawa Barat (Yuliana dan Winata, 2012) atau dengan memadukan peran pemerintah dan masyarakat yang dikenal dengan CoManagement yang bertujuannya untuk menghindari peran dominan dari satu pihak dalam pengelolaan sumberdaya perikanan. Dalam jangka panjang, cara ini diyakini akan meningkatkan kesadaran dan pendapatan masyarakat dengan bentuk pemanfaatan yang lestari (Alains et al, 2009).

Penguatan kelembagaan nelayan tersebut akan mendukung pelaksanaan model konseptual dalam hal perizinan, yaitu pembuatan dan penggunaan SOP perizinan oleh pemerintah perikanan yang mengurusi surat izin pengoperasian unit perikanan dan rumpon. Penentuan root definition yang kedua menitikberatkan pada permasalahan perizinan seperti pada Gambar 7 dan menghasilkan model konseptual (Gambar 9) yang bertujuan untuk menciptakan keteraturan dalam pengoperasian unit perikanan tonda dengan rumpon di perairan yang digambarkan dalam SOP perizinan yang dibuat oleh pemerintah daerah, dengan memperhatikan kepentingan dari seluruh pihak seperti nelayan, pengusaha, dan pemerintah.

\author{
CATWOE: \\ C (Costumers) \\ A (Actors) \\ $\mathrm{T}$ (Transformation) \\ W (Weltanschauung) \\ O (Owners) \\ $\mathrm{E}$ (Environmental constraints)
}

: Nelayan tonda Sendang Biru,

: Nelayan Sendang Biru, nelayan jaring luar Sendang Biru, masyarakat nelayan Sendang Biru, dan organisasi nelayan Rukun Jaya;

: Pembuatan peraturan lokal terhadap pengawasan perairan;

: Pengawasan perairan dilakukan secara aktif oleh seluruh masyarakat nelayan;

: Organisasi nelayan Rukun Jaya;

: Kebijakan pemerintah

\section{Root definition:}

Meningkatkan kekompakan nelayan, pengawasan, dan meminimalisir konflik melalui pembuatan dan pelaksanaan peraturan lokal yang ditetapkan bersama untuk meningkatkan hubungan sosial nelayan dan menjaga wilayah operasi penangkapan dan sumberdaya ikan didalamnya.

Gambar 6. CATWOE dan root definition terhadap permasalahan pengawasan pada unit perikanan tonda dengan rumpon di PPP Pondokdadap 


\section{CATWOE:}

$\mathrm{C}$ (Costumers)

A (Actors)

$\mathrm{T}$ (Transformation)

W (Weltanschauung)

O (Owners)

E (Environmental constraints)
: Nelayan dan pengusaha perikanan;

: Nelayan, organisasi nelayan Rukun Jaya, pengusaha perikanan, dan pemerintah perikanan daerah dan pusat (DKP dan KKP);

: Pembuatan Standard Operating Procedure (SOP) perizinan dengan jelas;

: Proses perizinan berjalan dengan efektif dan efisien;

: Pemerintah (DKP dan KKP);

: Kebijakan pemerintah daerah

\section{Root definition:}

Proses perizinan unit perikanan tonda dengan rumpon melalui pembuatan dan penggunaan SOP perizinan oleh pemerintah untuk menciptakan keteraturan dalam pengoperasian unit perikanan tonda dengan rumpon di perairan.

Gambar 7. CATWOE dan root definition terhadap permasalahan perizinan pada unit perikanan tonda dengan rumpon di PPP Pondokdadap

Pelaksanaan SOP secara benar oleh pemerintah dan nelayan secara bersamaan akan membantu kelancaran proses perizinan, dan tujuan yang diinginkan dari pelaksanaan model konseptual ini dapat tercapai. Pembenahan perizinan untuk unit perikanan khususnya unit perikanan tonda dengan rumpon diharapkan dapat meminimalisir dampak negatif dari pengoperasian unit perikanan dalam suatu kawasan perairan. Keaktifan dari seluruh pihak terkait seperti nelayan, organisasi nelayan, dan pemerintah sangat diperlukan dalam hal ini. Islam dan Yew (2013) dalam penelitiannya menyebutkan bahwa pengelolaan perikanan berbasis masyarakat di Bangladesh mampu meningkatkan pendapatan nelayan. Hal ini dikarenakan nelayan memperoleh akses yang lebih besar terhadap perikanan. Pengelolaan berbasis masyarakat ini telah merubah sikap nelayan untuk memiliki kesadaran yang lebih besar terhadap aturan perikanan dan mampu menyelesaikan konflik yang terjadi dengan lebih mudah.

\section{KESIMPULAN DAN SARAN}

\subsection{Kesimpulan}

1) Permasalahan yang terjadi pada sistem unit perikanan tonda dengan rumpon di PPP Pondokdadap adalah wilayah operasi yang semakin jauh, penurunan ukuran ikan tuna, kurangnya kesadaran dan kekompakan nelayan dalam menjaga perairan, konflik nelayan, dan kurangnya peran kelem- bagaan terhadap pengawasan dan perizinan;

2) Model konseptual yang direkomendasikan terdiri atas (1) pembuatan peraturan operasional penangkapan unit perikanan tonda dengan rumpon, (2) pembuatan dan pelaksanaan peraturan lokal pengawasan perairan, dan (3) pembuatan dan penggunaan SOP perizinan oleh pemerintah daerah.

\subsection{Saran}

1) Pemantauan sistem perikanan tonda dengan rumpon di PPP Pondokdadap harus dilaksanakan secara berkelanjutan, sehingga diperlukan penelitianpenelitian pendukung yang dapat mengkaji secara lebih detail, seperti analisis kapasitas penangkapan dan jumlah tangkapan optimal per unit kapal, analisis mutu hasil tangkapan, dan kuota atau jumlah optimal kapal tonda di PPP Pondokdadap;

2) Koordinasi antara nelayan, organisasi nelayan, dan pemerintah sebaiknya ditingkatkan agar pencapaian tujuan dari model konseptual dapat dilakukan secara tepat. 


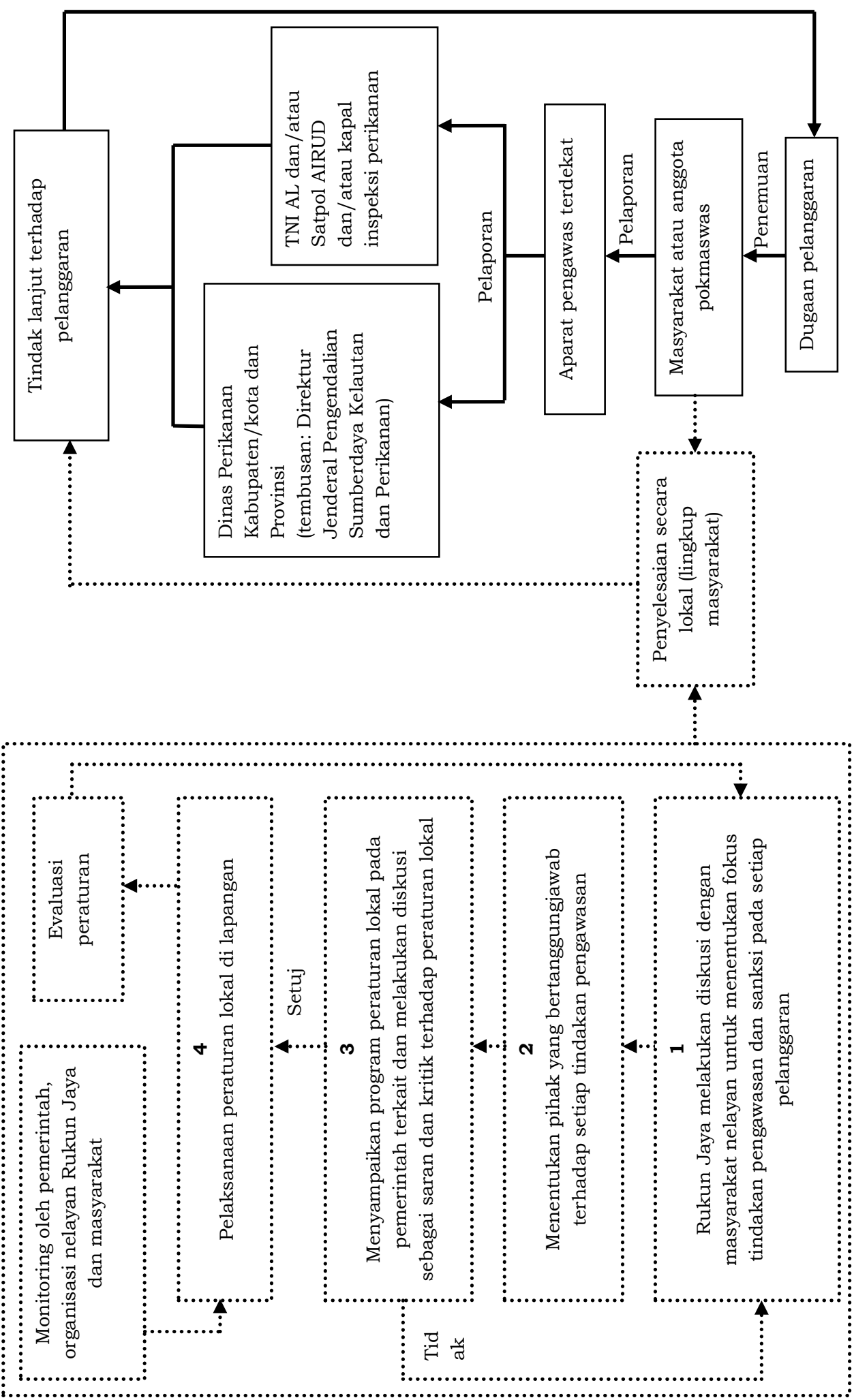

Keterangan: : sistem yang diperbaiki/ditambahkan

Gambar 8. Model konseptual pembuatan dan pelaksanaan peraturan lokal pengawasan perairan pada unit perikanan tonda dengan rumpon di PPP Pondokdadap 


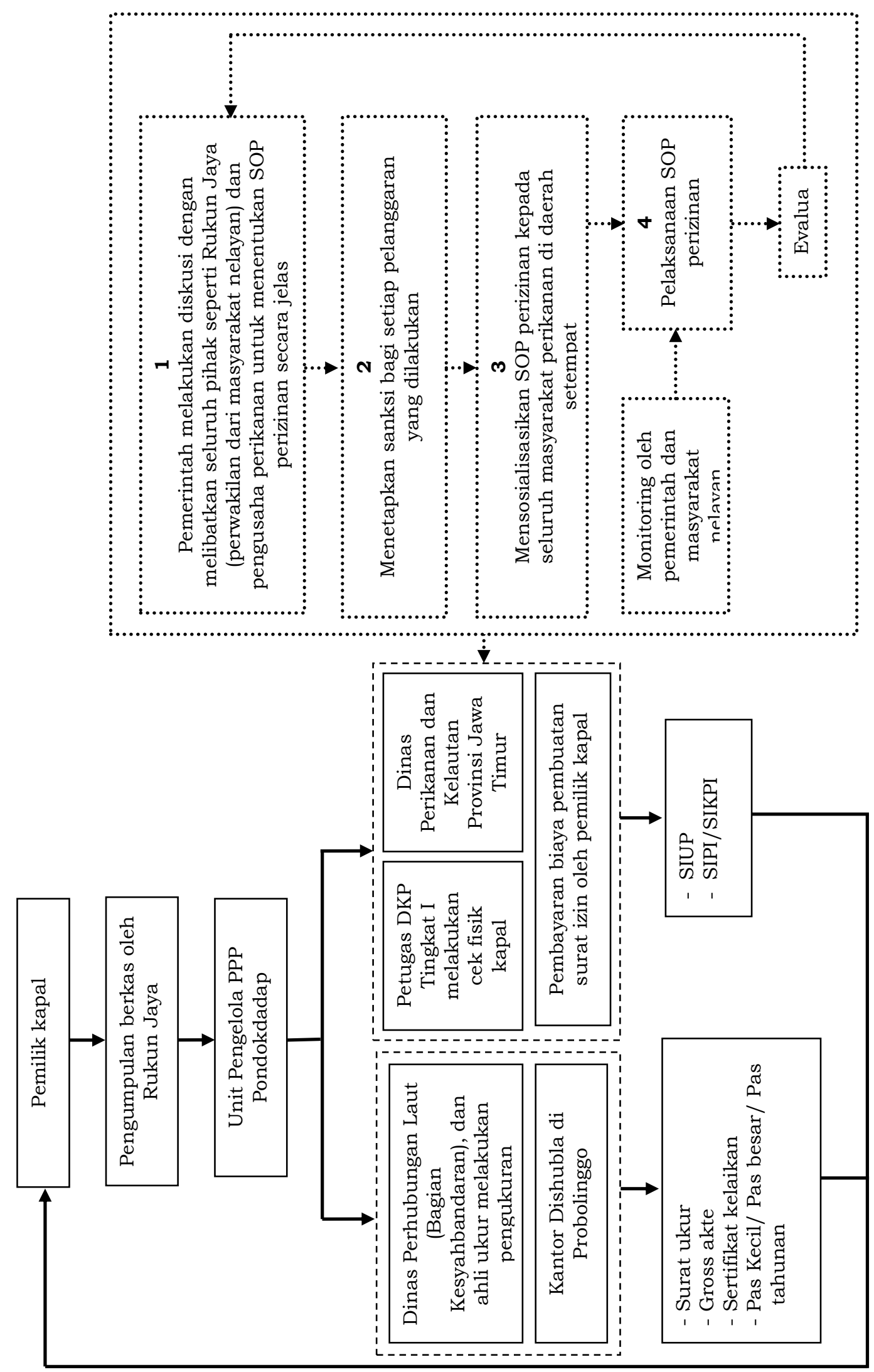

Keterangan: $\cdots \cdot \cdots \cdot \cdot$ : sistem yang diperbaiki/ditambahkan

Gambar 9. Model konseptual pembuatan dan penggunaan SOP perizinan oleh pemerintah daerah pada unit perikanan tonda dengan rumpon di PPP Pondokdadap 


\section{DAFTAR PUSTAKA}

Alains A M, Seprianti E P, Prilia H. 2009. Pengelolaan Sumberdaya perikanan berbasis masyarakat (PSPBM) melalui model Co-Management Perikanan. Jurnal Ekonomi Pembangunan [Internet]. [diunduh pada $2013 \mathrm{Apr}$ 18]. 10(2): 172-198. Tersedia pada: http:/ / publikasiilmiah.ums.ac.id/ handle/123456789/1066.

Alatas U. 2004. Analisis Hasil Tangkapan dan Respons Penglihatan Ikan Tongkol (Euthynnus affinis) pada Pancing Tonda Menggunakan Umpan Tiruan [tesis]. Bogor (ID): Institut Pertanian Bogor [Internet]. [diunduh pada 2013 Jul 01]. Tersedia pada: http://repository.ipb.ac.id/ handle/ 12345 6789/9042.

Astuti EM. 2005. Dimensi Unit Penangkapan Pukat Udang dan Tingkat Pemanfaatan Sumberdaya Udang di Perairan Laut Arafura. [skripsi]. Bogor (ID): Institut Pertanian Bogor.

Checkland P, Jim S. 1990. Soft System Methodology in Action. England (UK): John Wiley and Sons, LTD.

[DJPT] Direktorat Jenderal Perikanan Tangkap. 2013. Tahapan Perizinan [Internet]. [diunduh pada 2013 Jun 25]. Tersedia pada: http://www. perizinan.kkp.go.id/ pup/persyaratan_peng-ajuan_izin.php.

[DJPSDKP] Direktorat Jenderal Pengawasan Sumberdaya Kelautan dan Perikanan. 2013. Keputusan Menteri Kelautan dan Perikanan Nomor 58 Tahun 2001 [Internet]. [Diunduh pada 2013 Jun 25]. Tersedia pada: http://djpsdkp.kkp.go. id/pdf/KEPUTUSAN\%20MENTERI/KEPMEN 58_TAHUN_2001_LAMPIRAN.htm.

Habibi A, Dwi A, Sugiyanta. 2011. Perikanan Tuna-Panduan Penangkapan dan Penanganan. WWF-Indonesia [Internet]. [diunduh pada $2013 \mathrm{Jul}$ 01]. Tersedia pada: http://awsassets.wwf.or.id/.

Hastrini R, Abdul R, Putut HR. 2013. Analisis Penanganan (Handling) Hasil Tangkapan Kapal Purse Seine yang Didaratkan di Pelabuhan Perikanan Pantai (PPP) Bajomulyo Kabupaten Pati. Journal of Fisheries Resources Utilization Management and Technology UNDIP. 2(3): 1-10.
Ismanto DT, Taufik FN, Alam B. 2013. Desain Sistem Pendingin Ruang Muat Kapal Ikan Tradisional Menggunakan Es Kering dengan Penambahan Campuran Silika Gel. Jurnal Teknik Pomits. 2 (2).

Martin R, Irmayanti M. 2011. Ritual Petik Laut pada Masyarakat Nelayan Sendang Biru, Malang: Sebuah Telaah Budaya Bahari. International Conference ICSSIS; (2011 Jul 18-19); Depok, Indonesia. Depok (ID): Fakultas Ilmu Pengetahuan Budaya Universitas Indonesia. hlm 340-351 [Internet]. [diunduh pada 2013 Jun 28]. Tersedia pada: https://icssis. files.wordpress.com/2012/05/ 1819072011_27.pdf.

Pillai N G dan Satheeshkumar P. 2012. Biology, Fishery, Conservation and Management of Indian Ocean Tuna Fisheries. Ocean Science Journal. 47(4): 411-433.

Ross A. 2011. Model Pengelolaan Perikanan Pelagis secara Berkelanjutan di PPN Prigi, Trenggalek, Jawa Timur [tesis]. Bogor (ID): Institut Pertanian Bogor.

Saputra, S W. 2011. Produktivitas dan Kelayakan Usaha Tuna Longliner di Kabupaten Cilacap. Jurnal Saintek Perikanan. 6(2): 84-91.

Sondita M F A. 2011. Sebuah Perspektif: Rumpon sebagai Alat Pengelola Sumberdaya Ikan - Buku II New Paradigm in Marine Fisheries: Pemanfaatan dan Pengelolaan Sumberdaya Perikanan Laut. Tri W N, Domu S, Akhmad S, Shinta Y, editor. Bogor (ID): Departemen Sumberdaya Perikanan.

Sugiyono. 2007. Statistika untuk Penelitian. Bandung (ID): CV ALFABETA.

Sulaiman. 2010. Model Alternatif Pengelolaan Perikanan Berbasis Hukum Adat Laot di Kabupaten Aceh Jaya Menuju Keberlanjutan Lingkungan yang Berorientasi Kesejahteraan Masyarakat [tesis]. Semarang (ID): Program Magister Ilmu Hukum, Program Pascasarjana Universitas Diponegoro [Internet]. [diunduh pada 2013 Jul 01]. Tersedia pada: http://eprints.undip.ac.id/24019/1 / Sulaiman.pdf.

[UPPPP Pondokdadap] Unit Pengelola Pelabuhan Perikanan Pantai Pondokdadap. 2013. Laporan Monitoring Pangkalan Pendaratan Ikan (PPI) 
dan Pelabuhan Perikanan (PP): Laporan Bulanan Tahun 20082012. Malang (ID): UPPPP Pondokdadap.

Williams B. 2005. Soft System Methodology [Internet]. [diunduh pada 2012 Des 03]. Tersedia pada: http:// users.actrixs.com/bobwill/ssm.pdf.

Yuliana E dan Adi W. 2012. Pengaruh Karakteristik dan Persepsi terhadap Tingkat Partisipasi Anggota dalam Kelompok Masyarakat Pengawas (Pokmaswas) Sumberdaya Kelautan dan Perikanan. Jurnal Bumi Lestari. 12(2): 251-259.

Zulbainarni N. 2012. Teori dan Praktik Pemodelan Bioekonomi dalam Pengelolaan Perikanan Tangkap. Bogor (ID): PT Penerbit IPB Press. 